\title{
HYBRIDIZATION OF SNAKE RIVER CUTTHROAT IN THE LOWER GROS VENTRE RIVER
}

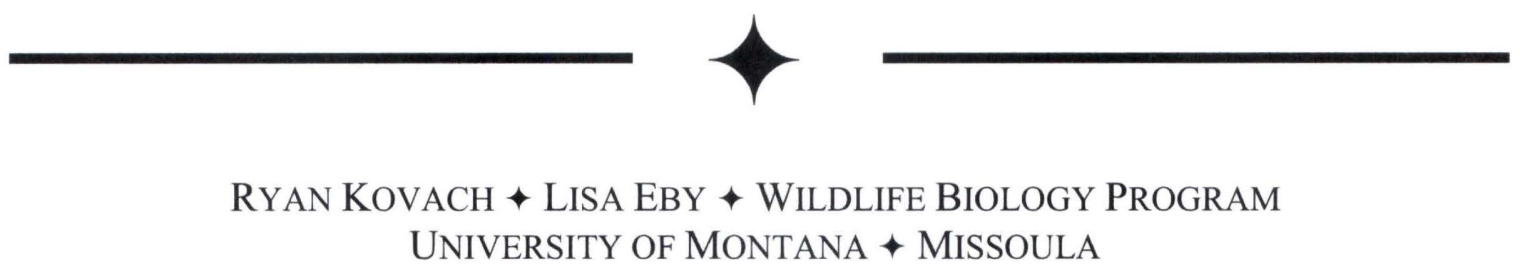

\section{$\downarrow$ INTRODUCTION}

The cutthroat trout Oncorhynchus clarki is Wyoming's only native trout. The Yellowstone cutthroat trout (Oncorhynchus clarkii bouvieri) is designated as a "species of special concern" by a number of agencies and conservation groups. Although the Yellowstone cutthroat trout has recently avoided federal listing because of robust headwater populations (USFWS 2006), they face continued threats across their range. The fine-spotted Snake River native trout is a morphologically divergent ecotype of the Yellowstone subspecies, although it is not genetically distinguishable (Allendorf and Leary 1988, Novak et al. 2005). The Gros Ventre, an important tributary of the Snake River located partially in Grand Teton National Park, historically supported robust populations of finespotted Snake River cutthroat trout. Principal threats to Gros Ventre native trout, especially in the lower end of the drainage within the park boundaries, include both water diversions (loss of water and fish into irrigation ditches) and presence of exotic species.

As a result of the ubiquitous distributions of exotic fish that displace or hybridize with native trout, we are seeing an ever increasing number of case studies where conservation efforts that increase connectivity across the landscape result in exotic fish expansion and subsequent problems for native fish. In fact, conservation efforts to preserve genetically pure cutthroat trout populations include the placement of barriers to avoid the influence of exotic species (e.g., Novinger and Rahel 2003). Thus the benefits of increase in flow, habitat, and potential production of trout within the Gros Ventre system needs to be weighed against the potential expansion of exotic and hybrid fish into the larger Snake River system. An important component of this project is the potential for hybrid fish to move into the larger Snake River system with increased connection between the Gros Ventre and the Snake River. The presence of rainbow trout and rainbow $\mathrm{x}$ cutthroat trout hybrids has been documented in the Gros Ventre River system (Kiefling 1973, 1978, Novak et al. 2005). Hybrid fish were recently collected in samples above Slide Lake (Novak et al. 2005). The degree to which the Gros Ventre River above Slide Lake is connected to the Lower Gros Ventre is unknown. As we consider increased connection to the Snake River, we need to understand the degree to which the population in the Lower Gros Ventre is hybridized. This project allows us to evaluate whether hybrids are common in the lower Gros Ventre and understand where they occur.

Thus, connection to the large Snake River system could be detrimental to the genetically pure population of cutthroat trout found in the main Snake River system. Understanding the habitat use and movement corridors of cutthroat trout, rainbow trout, and hybrid cutthroat and rainbow trout is important for determining the best management practices for Snake River cutthroat in the Gros Ventre and the larger Snake River system. Native Yellowstone cutthroat trout have been extirpated from $70 \%$ of the perennial streams which currently support trout because of hybridization with rainbow trout and competition with brook 
and brown trout (Kruse et al. 2000). Thus, prevention of the expansion of exotic species including hybrid fish is a serious concern for the system.

\section{Objectives}

(1) Examine the level of hybridization in the Lower Gros Ventre River system (from diversion survey, spring creek survey, and lower river survey).

(2) Check the visual assignment of fish (rainbow, hybrid and cutthroat) that will be radio-tagged to strengthen our inferences regarding movement and spawning locations for pure versus hybrid fish.

\section{$\uparrow \quad$ METHODS}

We used a variety of techniques including backpack electrofishing, river boat electrofishing in collaboration with Wyoming Game and Fish, as well as hook and line sampling. In the summer of 2007 , we collected trout in major diversion ditches off of the Gros Ventre, two spring creeks (Spring Creek and Flat Creek), and in the Gros Ventre River below Slide Lake and near Kelly. In addition, we collected samples from two of the diversion ditches in the fall of 2007. For every trout, we performed a visual call for identification (cutthroat, hybrid, rainbow), measured the total length $(\mathrm{mm})$ and removed a small sliver of the caudal fin for genetic analysis. We randomly subsampled from our catches to pick the samples to be analyzed. We have analyzed 25-28 fish from each spring creek (Spring and Flat Creeks), and 218 fish from the lower Gros Ventre including samples collected near Slide Lake, Kelly, Price Lucas, and Spring Gulch ditches. During the summer the entire river was diverted down Spring Gulch, therefore this was considered the lower extent of the study section. Finally, we analyzed 36 fish that had been radiotagged in the lower Gros Ventre during the fall 2007.

Samples were stored in ethanol and returned to the Conservation Genetics Lab at The University of Montana for processing. We extracted DNA and used a Pronase solution to lyse cells. Protein precipitation was completed using PureGene. We amplified fourteen microsatellite loci diagnostic for hybridization between cutthroat and rainbow trout using fluorescently labeled primers in multiplex polymerase chain reactions (PCR). Microsatellite PCR product was visualized on an ABI 3130 sequencer. We scored allele sizes using Genemapper version 3.7.

We calculated both the proportion of individuals that had rainbow trout alleles present, as well as a hybrid index score (HIS). If any rainbow trout alleles were present in genotyping, we considered the individual a hybrid. The hybrid index score is the number of rainbow alleles divided by the number of total alleles at these diagnostic sites. Therefore, pure cutthroat trout would have a hybrid index score of 0 while a hybrid index score of 1 would be a pure rainbow trout.

\section{$\downarrow \quad$ RESULTS}

\section{Hybridization in the Lower Gros Ventre}

We detected hybridization between rainbow trout and cutthroat trout throughout the Lower Gros Ventre and its irrigation diversions. In the river system, approximately $23 \%$ of the individuals randomly sampled were hybridized. The overall hybrid index score for the Gros Ventre River was 0.072 with rainbow trout alleles being highly skewed towards Yellowstone cutthroat trout backcrosses. HIS's were widely distributed across individuals in the Gros Ventre, from pure cutthroat (HIS $=0$ ) to pure rainbow trout (HIS=1) (Figure 1). In comparison, there were few hybrids in the samples of the nearby spring creeks with only $4 \%$ of the sample ( 1 in sample of $28-30$ fish) were hybrids. These few individuals from spring creeks also had very low HIS.

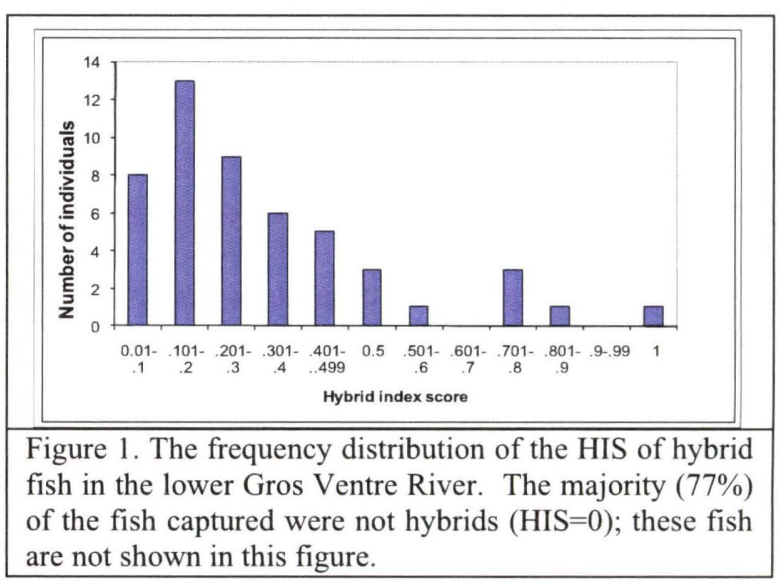


The fact that we captured fish with very high HIS's implies a separation of heterospecific spawning populations, where pure (or almost pure) rainbow trout remain present in the system. Multiple genetic signals (including tests for Hardy-Weinberg equilibrium and Bayesian clustering) indicate there may be more than one hybridizing population within the Gros Ventre River.

Hybridization rates varied across the linear river gradient and temporally. Samples collected from downstream sites (i.e., Price Lucas and Spring Gulch) had higher proportions of hybrids in the sample than upstream sampling locations (Figure 2). Additionally in October, we captured fish in these downstream sites that had higher hybrid index scores than summertime samples. These differences in space and time associated with the capture of hybridized individuals indicate that hybrids may be moving around the system differently than the pure cutthroat trout. This will be further investigated by other efforts that will pit tag fish in the upcoming field season (UM) and the examination of movements of the radio-tagged fish that are being followed in a collaborative project. Jim Gregory (Gregory Aquatics) is contracted by Trout Unlimited and in collaboration with Wyoming Game and Fish has radio-tagged fish across a range of levels of hybridization to examine differences in habitat use and movement.

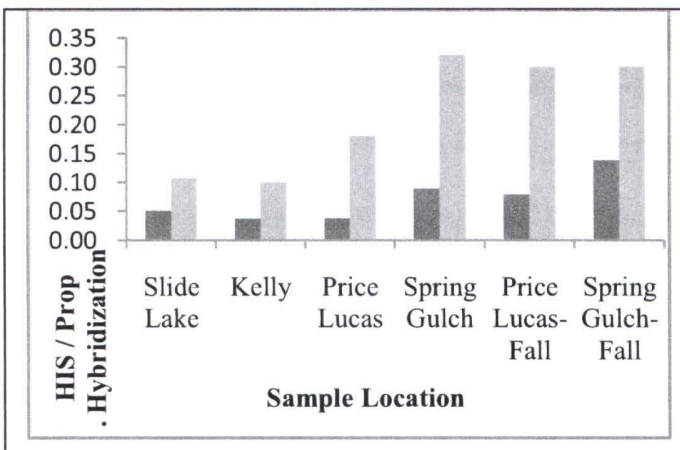

Figure 2. Average hybrid index score (HIS, white bars) and average proportion of the individuals that were hybridized in the samples (black bars). Slide Lake, Kelly, Price Lucas, and Spring Gulch were sampled in July. Price Lucas and Spring Gulch were sampled again in the fall (October/November) of 2007.

\section{Assignment of radio-tagged fish}

The second objective associated with this proposal was to check the assignment of the fish (pure cutthroat trout, hybrid, or rainbow trout) that were radio-tagged in the fall of 2007. This is an important component because it is difficult to properly visually identify cutthroat and rainbow hybrids. The genetic analysis with the visual identification is necessary to ensure that we are making appropriate inferences regarding the status of these individuals.

The visual calls were correct $86 \%$ of the time. All individuals miscategorized had relatively high HIS but were categorized as pure rainbow trout (Figure 3). In discussing this with Jim Gregory, he did know that some of the fish that were categorized as rainbow trout were likely hybridized fish. The radiotagged fish do demonstrate the entire range of the hybrid index scores. From previous studies, the fish that are most often incorrectly classified are cutthroat rainbow hybrid with relatively low HIS (Leary et al. 1996, Weigel et al. 2002). These fish are not in the radio-tagging study but do make up the majority of the hybrids in the Gros Ventre population are those that range from 0.01 to 0.4 HIS. Therefore, we will be examining the reliability of our visual calls for the random samples in the future.

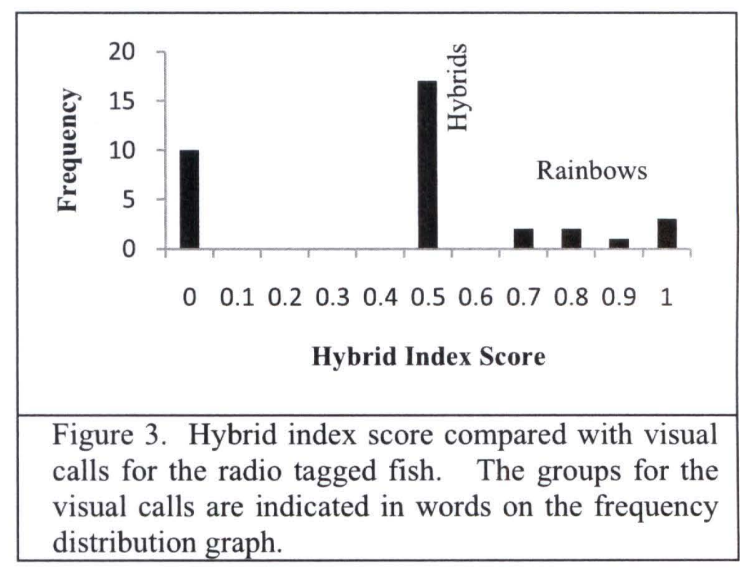

\section{$\downarrow$ SUMMARY}

The Gros Ventre River is a potential source of hybrids to the larger Snake River system. The Gros Ventre not only contained higher proportions of hybrids compared with nearby spring creeks, it also has fish with very high hybrid index scores, including some pure rainbow trout. Thus, examining the relative risks associated with the movement and dispersal of 
hybrids should be considered in the management of this system. This project has provided evidence (through the bimodal distribution of HIS) that there are likely separate spawning populations of rainbow trout or fish that are primarily rainbow trout. Genetic analyses would predict at least two spawning aggregations of highly hybridized fish. Given these results, we would recommend examining the potential of suppressing these highly hybridized breeding populations to minimize their future impact on this important Snake River cutthroat conservation region. Finally, this project has described a pattern in the habitat use and/or movement (spatial and temporal patterns) of hybrids in this system that we hope will be elucidated further in the 2008 field season through both additional tagging by $\mathrm{UM}$ and continued collaboration with Jim Gregory, Gregory Aquatics.

\section{$\downarrow$ ACKNOWLEDGEMENTS}

We could not have done this work without the field help and knowledge of the folks at Wyoming Game and Fish (Rob Gipson and crew), Trout Unlimited (Scott Yates and crew), Thomas Chandler, and Jim Gregory. In addition, Sally Painter, Steve Amish, and Matt Corsi (especially Sally!) were invaluable in helping with the laboratory procedures and genetics analyses. Finally, Ryan Kovach was partially funded by the MILES undergraduate research scholarship, Irene Evers research scholarship, and the Davidson Honor's College Research Scholarship.

\section{$\downarrow$ Literature Cited}

Allendorf, F. W., and R. F. Leary. 1988. Conservation and distribution of genetic variation in a polytypic: the cutthroat trout. Conservation Biology. 2:170-184.

Kiefling, J.W. 1973. Habitat evaluation of the Snake River and tributary streams. Part I Gros Ventre River Habitat Evaluation. Wyoming Game and Fish Commission Cooperative Research Project No. 4. Segment 6, Job 2, F-37-R-6. March 1973
Kiefling, J.W. 1978. Studies on the ecology of the Snake River cutthroat trout. Wyoming Game and Fish Department Fisheries Technical Bulletin. 3:198pp.

Kruse, C.G., W.A. Hubert, F.J. Rahel. 2000. Status of Yellowstone cutthroat trout in Wyoming waters. North American Journal of Fisheries Management. 20:693-705.

Leary, R.F., W.R. Gould, and G.K. Sage. 1996. Success of basibranchial teeth in indicating pure populations of rainbow trout and failure to indicate pure populations of westslope cutthroat trout. North American Journal of Fisheries Management. 16:210-213.

Novak, M.A., J.L. Kershner, and K.E. Mock. 2005. Molecular genetic investigation of Yellowstone cutthroat trout and finespotted Snake River cutthroat trout. A report in partial fulfillment of: agreement \#165/04 Wyoming Game and Fish Commission Grant. 48 pp.

Novinger, D.C. and F.J. Rahel. 2003. Isolation management with artificial barriers as a conservation strategy for cutthroat trout in headwater streams. Conservation Biology. 17:772-781.

USFWS (United States Fish and Wildlife Service). 2006. Status review: Yellowstone cutthroat trout Oncorhynchus clarkii bouvieri. U.S. Fish and Wildlife Service, Denver, Colorado.

Weigel, D.E., J.T. Peterson, and P.A. Spruell 2002. Model Using Phenotypic Characteristics to Detect Introgressive Hybridization in Wild Westslope Cutthroat Trout and Rainbow Trout. Transactions of the American Fisheries Society. 131:389-403. 